378.147::811.163.41(477.74)

https://doi.org/10.18485/msc_saopstenja.2018.48.1.ch18

Олга Н. НОВАК*

Одеський національний університет

„И. И. Мечников”
Прегледни рад

Примљен: 15. 10. 2018.

Прихваћен: 03. 12. 2018.

\title{
ПРОБЛЕМИ И ПЕРСПЕКТИВЕ СРБИСТИКЕ НА УНИВЕРЗИТЕТУ „И. И. МЕЧНИКОВ” У ОДЕСИ
}

\begin{abstract}
Сербокроатистика и нарочито србистика у Одеси имају дугу традицију од самог оснивања Императорског новоросијског (Одеског) Универзитета. Славистичке студије биле су и остале један од приоритета нашег универзитета. Срдачно се захваљујемо МСЦ-у на великој помоћи за стручно усавршавање наставника српског језика. Међутим, нажалост, споразуми о сарадњи између нашег универзитета и водећих универзитета у Србији још увек нису продужени, што компликује сарадњу и размену студената и наставника. Нажалост, данас је Одеса на периферији научних и дипломатских догађаја, а односи између амбасада, као и министарстава наука и културе Украјине и Србије и даље су доста сложени. Наши студенти су скоро изоловани од културних догађаја у организацији Амбасаде Репблике Србије у Кијеву и имају ограничене могућности употребе језика. Сматрамо да би се ситуација могла побољшати отварањем Српског културног центра у Одеси који би подржавао интересовање студената за учење српског језика и културе и јачао културне везе међу нашим народима.

Кључне речи: Универзитет „И. И. Мечников” у Одеси, славистика, србистика, јужно-словенски језици.
\end{abstract}

Данашњи Одески, некадашњи Императорски новоросијски универзитет (ИНУ), отворен је на месту некадашњег Ришељеовог лицеја 13. маја 1865. године и састојао се од три факултета - историјско-филолошког, физичко-математичког и правног. Од првих дана оснивања универзитета славистика је била препозната као приоритет. Интересовање за славистику и њен свестрани развој на Императорском новоросијском универзитету било је условљено и односом владе према стварању универзитета на граници са јужнословенским светом. У Санкт Петербургу су сматрали да се мисија овог универзите-

*olganovak2@gmail.com 
та састоји у стварању атмосфере поверења балканских Словена према Руској царевини и њиховом укључивању у спољашњу политику Русије.

Будући да је универзитет као образовни и научни центар био намењен, између осталог, и задовољењу образовних потреба Јужних Словена, образовању научног кадра за земље Балканског полуострва, као и додатном руско-јужнословенском зближавању, у руској престоници је постојала свест о недостатку кадра који би ове задатке испунио. Зато су током шездесетих и почетком седамдесетих година XIX века на универзитет позивани предавачи од којих се очекивало да дају допринос проучавању словенских народа. Осим тога, на ова радна места бирани су млади људи, који су изразили намеру да се баве славистиком, пружана је подршка предавачима различитих предмета да у оквиру бављења науком истражују питања словенске проблематике. Ово је допринело томе да се Императорски новоросијски универзитет у Одеси развије у центар за проучавање западнословенске и јужнословенске тематике, центар који је окупљао историчаре, филозофе, правнике. На универзитету је сваке године студирало између 60 и 100 страних држављана, углавном представника балканских земаља.

Већ 1865. године, одмах по оснивању Новоросијског универзитета, Виктор Иванович Григорович био је позван на место управника Катедре за историју и књижевност словенских народа. Он је убрзо потом изабран и за декана Историјско-филолошког факултета, где је радио 11 година, све до 1876.

В. И. Григорович је у том тренутку већ био познати истраживач у области славистике и колекционар старих словенских рукописа. Учинио је невероватно много за организацију Одсека за славистику и за образовање студената.

Још док је радио на Казањском универзитету, В. И. Григорович, рођен у градићу Балта у околини Одесе, добар познавалац ове области, изнео је аргументе у прилог оснивања Катедре за славистику у оквиру Ришељеовог лицеја, на чијој основи је касније створен универзитет. Он је донирао 650 књига из области славистике, уз уговор који је налагао да се књиге чувају у специјалном фонду и на основу кога је он као дародавац задржавао право коришћења библиотеке. Књиге В. И. Григогоровича биле су први легат Научне библиотеке универзитета.

За време боравка В. И. Григоровича у Одеси у његовој колекцији су се налазили бисери словенског рукописног наслеђа које је сачувао од заборава и уништења: Маријинско јеванђеље из XI века; Охридски апостол из XII века; Слепченски апостол, палимпсест, чији је словенски текст написан преко грчког брзописа из X века; Григоровичев паримејник који датира из XII-XIII в., Григоровичев ирмологиј са почетка XIII века донет из манастира Хиландара; одломак Катихеза Теодора Студита из ХІІІ века, Четворојеванђеље из Хиландара (XIII-XIV) и бројни други рукописи.

Краткотрајна, али запажена делатност личности као што је био В. И. Григорович поставила је чврсте темеље за функционисање и развој славистичких студија у Одеси. Тематике српске историје В. И. Григорович се дотакао у чланку „О учешћу Срба у нашим друштвеним односима”. 
Савремена историографија сматра да је највећи ауторитет у области историје средњовековне Србије на територији Украјине био историчар права Фјодор Иванович Леонтович, који је на универзитет дошао заједно са В. И. Григоровичем. У периоду између 1869. и 1877. године Ф. И. Леонтович се налазио на месту ректора универзитета, бринуо је о успешном раду Друштва Ћирила и Методија. Ф. Леонтович је 1870 . године одабран за сталног члана Српског ученог друштва, а 1889. године био је један од твораца Историјско-филолошког друштва при ИНУ, које је активно радило од 1889. до 1923. године.

Године 1871. за ванредног професора Катедре за компаративну лингвистику изабран је Ватрослав Јагић (Игнатиј Викентијевич), који је у Одеси у периоду 1872-1874. године радио на проучавању „Хиландарских листића”, „Житија Стефана Лазаревића” и других рукописа који су се чували на ИНУ.

На ИНУ је 1868. године почео да ради ученик Ф. И. Буслајева, дописни члан Московског археолошког друштва, проучавалац књижевности Иван Степанович Некрасов, чија је основна област научног истраживања била староруска хагиографија. Године 1871. је, вероватно под утицајем јаке славистичке школе створене на ИНУ, написао и објавио рад „Пахомије Србин - писац XV века". Од 1874. до 1890. године био је декан Историјско-филолошког факултета, а у периду од 1890. до 1895. године ректор Универзитета. На све начине је поспешивао развој славистичких истраживања на универзитету.

На Катедру за словенске језике је 1871. године био примљен Александар Александрович Кочубински, који је постао близак сарадник В. И. Григоровича. Он је рођен у Бесарабији (у Акерману), завршио је гимназију при Ришељеовом лицеју са златном медаљом, а затим се школовао на Московском универзитету. Током дугог и плодног рада на ИНУ, А. А. Кочубински се показао као зрео научник, који је наставио традицију одеске славистичке школе. Његов рад „О питању међусобног односа словенских наречја. Основна вокализација група са ликвидама...” (1878) представља озбиљно компаративно истраживање словенских система вокализма и настао је као круна његовог двогодишњег научног боравка у словенским земљама и славистичким центрима Западне Европе.

Одески универзитет памти и поноси се чињеницом да је управо овде започео научни пут академика Александра Белића. У школској 1895/96. години Александар Белић се уписао на Историјско-филолошки факултет Новоросијског универзитета, где је са огромним интересовањем посећивао славистичка предавања Александра Александровича Кочубинског, затим предавања истакнутих научника Штерна и Никитског из класичне филологије и професора Винера из историје. Овде проналази рукописе значајне за српску културу, конкретно „Збирку српских рукописа”, за коју је је сматрао да је од изузетног значаја за историју српског језика XV века и проучавања реформе Константина Филозофа, а у којој су се налазили „Опис живота деспота Лазара Константина Филозофа” и „Књига беседа”. Александар Белић је пронашао и „Житије Свете Петке” и управо овај рукопис био је предмет његовог првог објављеног научног рада. 
Катедра за општу и словенску лингвистику Одеског државног универзитета „И. И. Мечников” основана је 1968. године са циљем да одговори на потребе за квалитетнијом наставом лингвистичких и славистичких дисциплина. На овај начин је поновно успостављена историјска правда и континуитет научног наслеђа, а катедра је настала као последица обнављања старе традиције Новоросијског (Одеског) универзитета, укључујући и традицију оснивача, која се заснивала на посебној пажњи и искреном научном интересовању за јужнословенске језике и културе. Захваљујући ентузијазму, ауторитету и високом научном нивоу познате слависткиње Аделаиде Константиновне Смољске студенти русистике и украјинистике су од прве године рада катедре учили српскохрватски језик као други словенски језик. Професорка Смољска активно је радила на популаризацији словенских језика и славистичких истраживања, а на ОНУ је радила неколико деценија. Њена научна интересовања су у највећој мери била везана за сербокроатистику, а дуго времена је А. К. Смољска била једини доктор србистичких наука у Украјини. Бавила се проблемима граматичких категорија, међусобног односа семантичких и граматичких категорија, историјом славистике, објављивала је радове посвећене словенским споменицима, митологији Јужних Словена и др. Укупно је објавила преко 130 научних радова.

Заједно са тадашњим управником катедре, професором Јуријем Александровичем Карпенком, Аделаида Константиновна је организовала и реализовала праксу са студентима у области топонимије и бавила се проучавањем топонима јужнословенског порекла у Украјини, на територији некадашње Славеносрбије и Одеске области. По налогу Ј. А. Карпенка организована су студентска путовања у села у Одеској области - Чорнохирка, Словјаносербска, Серби, где су студенти на терену прикупљали информације о граничарима, оснивачима ових војних насеља. Као резултат заједничког рада проф. Смољске и Карпенка настао је чланак „Јужнословенски трагови у топонимици Југа Украјине”.

Одбрана њене докторске дисертације „Развој именске творбе речи у српскохрватском књижевном језику (фемининуми)" 1993. године на Московском универзитету, бројне публикације после одбране дисертације, „Словенски зборник” који је уређивала до краја свог живота (2004. године), организација студентских „Словенских вечери” и међународних годишњих Ћирило-Методијевских конференција, које су организоване од 1995. године и чиме је обновљена универзитетска традиција коју је успоставило Друштво Ћирила и Методија у време И. Григоровича, давали су колективу одеских филолога осећај сигурности и оптимизам у неповољним временима за украјинску науку деведесетих година, активирајући славистичка и, генерално, лингвистичка истраживања на ОНУ.

Под руководством А. К. Смољске проучаване су карактеристике преписа Типика Светог Саве (И. Андријанова; Д. Мостова), историја српске лексикографије (А. Иљасов), карактеристике превода Чехова на српскохрватски језик (И. Курило) и др. Нажалост, околности су биле такве, да млади нису били заинтересовани за даљи рад на универзитету, нарочито када њихове 
менторке више није било на катедри. Доц. др О. М. Новак (Пејчева) једина је ученица Аделаиде Константиновне која је после одбране доктората из славистике (Нестабилни консонанти у јужнословенским језицима и дијалектима, 2003) остала на универзитету, на катедри са које је потекла.

Српскохрватски, а касније српски језик на катедри су дуго времена предавали Ерика Еразмусовна Минкевич и проф. Николај Иванович Зубов, који је од 1993. до 2009. године био управник Катедре за општу и словенску лингвистику, али је, нажалост, прешао на други факултет и ради на другом универзитету. Захваљујући проф. Смољској катедра је дуги низ година одржавала блиске контакте са Универзитетом у Новом Саду и Универзитетом у Београду и Међународним славистичким центром у Београду. Захваљујући овим давним личним и научним везама, као и напорима О. Новак и Е. Минкевич на Филолошком факултету ОНУ „И. И. Мечников”, студенти русистике и украјинистике добили су могућност да поред основне стручне квалификације стекну и струку србиста, по аналогији са већ постојећом могућношћу стицања струке полониста. Чини се да је ово једини случај у последњим деценијама да се србистичке студије на неком универзитету не укидају, него отварају.

Филолошки факултет је веома заинтересован за сарадњу са српским колегама и позива све заинтересоване на рад на заједничким пројектима. Сматрамо да би оваква сарадња могла бити веома продуктивна и корисна за обе стране. Пре свега, неопходно је потписати споразуме о међууниверзитетској сарадњи и међуфакултетској сарадњи филолошких факултета, што, ма колико то чудно звучало, још увек није учињено, а што онемогућава размену студената и професора.

Катедра за општу и словенску лингвистику искрено захваљује Међународном славистичком центру за усавршавања наставника српског језика и тежи продубљивању научних и образовних веза са другим славистичким центрима, као и да потпуније искористи своје људске ресурсе, трудећи се да поврати некадашњи ниво и статус Одеског универзитета као европског славистичког центра и да педесетогодишњицу свог постојања обележи савременим, иновативним пројектима са старим и новим пријатељима и колегама славистима из различитих земаља.

Ипак, славистика на југу Украјине се данас суочава са одређеним тешкоћама. Као важан проблем чини нам се то што се у савременој Украјини Одеса, нажалост, налази на периферији најважнијих културних процеса и дешавања везаних за наше земље, које организују дипломатске установе у Кијеву, као што су Недеља српског филма, изложбе, сусрети са истакнутим личностима савремене Србије. Сматрамо да би се ситуација могла побољшати отварањем Српског културног центра у Одеси који би подржавао интересовање студената за учење српског језика и културе и јачао културне везе међу нашим народима. Верујемо да србистика у Одеси нема само богату историју, већ и светлу будућност, уколико се сви објединимо и учинимо све што од нас зависи. 


\section{ЛИТЕРАТУРА}

Василијевић Драгана. Србистика на украјинским универзитетима // Лингвистичке актуелности - 2015, бр. 26, стр. 22-53.

Войцева О. А., Смольська А. К. Славістичні традииії Одеського універсиmету // Славістичні науково-дослідні центри в Україні (вчора - сьогодні - завтра) : мат. всеукр. науково-практ. конф. (м. Київ, 25-26 травня 1994 р.). - Київ, 1995. - С. 70-73.

Історія Одеського університету (1865-2000) / Л. О. Ануфрієв, С. О. Аппатов, Ю. О. Амброз та ін.; Ред. В. А. Сминтина; Одеський держ. ун-т ім. І. Мечникова. - О.: АстроПринт, 2000. - 226 с.

Николић М. Р. Прилози упознавању живота и рада Александра Белића // Наш језик XIV, 1964, стр. 169-188.

Одеський національний університет ім. I. І. Мечникова за роки незалежності України: 1991-2005 рр. / гол. ред. В. А. Сминтина. - 2-е вид. - О. : Астропринт, 2005. $-552 \mathrm{c}$.

Пейчева О.М. Нестабільні консонанти у південнослов'янських мовах та їх діалектах: Автореф. дис... канд. філол. наук: 10.02.03. - Київ, 2003. - 22 с.

Смольская А. К., Карпенко Ю. А. Южнославянские следь в топонимии юга Украины // Onomastica Jugoslavica. - Zagreb, 1975. - № 5. - С. 67-80.

Смольська А. К., Бондар О. І. Еволюиія семантики дієслів руху в аспекті типології украӥнської та сербської мов // Мовознавство (К.), 2003, № 2-3, с. 142-144.

Степанов Є. М. Розвиток наукових ідей І. В. Ягича в Одеській історико-філологічній школі // Мова - 2013, №20 - С. 51-55.

Степанов Є. М. Наукові ідеї та подвижнищька діяльність Віктора Івановича Григоровича у розвитку філологічної иколи Одеського університету (до 200-річчя вченого та 150-річчя ОНУ імені I. I. Мечникова)// Вісник ОНУ. Сер.: Філологія. 2015. Т. 20, вип. 2(12) - С. 28-40.

Хронологічний покажчик наукових i науково-методичних праць доктора філологічних наук, професора А. К. Смольської //«Людиною бути - це мистецтво». Збірник пам'яті доктора філологічних наук, професора Аделаїди Костянтинівни Смольської. Одеса, ОНУ, 2014 - С. 251-265. 
Olga N. Novak

SERBIAN STUDIES IN ODESSA I. I. MECHNIKOV NATIONAL UNIVERSITY

Summary

Slavic studies and especially Serbian studies in Odessa have long tradition since the foundation of the Imperial Novorossiysk University. Slavic studies are still challenging in the scientific work of Odessa I. I. Mechnikov National University. The Department of General and Slavic Linguistics collaborates with the Faculty of Philology of the University of Belgrade and the Faculty of Philosophy of Novi Sad University, as well as with the International Slavic Center in Belgrade, which constantly assists in the education and development of specialists in Serbian language and culture. However, unfortunately, today Odessa remains on the periphery of Ukrainian-Serbian intercultural relations and events organized by diplomatic institutions in Kyiv. We believe this situation could be changed by the establishment of a Serbian cultural center in Odessa.

Key words: Odessa I. I. Mechnikov National University, Slavic Studies, Serbian studies, Southern Slavic Languages. 